Heitor Cantarella; Raffaella Rossetto. "FERTILIZERS FOR SUGARCANE", p.405-422. In Luis Augusto Barbosa Cortez (Coord.). Sugarcane bioethanol - R\&D for Productivity and Sustainability, São Paulo: Editora Edgard Blücher, 2014. http://dx.doi.org/10.5151/BlucherOA-Sugarcane-SUGARCANEBIOETHANOL_39

\title{
FERTILIZERS FOR SUGARCANE
}

\author{
Heitor Cantarella and Raffaella Rossetto
}

\section{INTRODUCTION}

Sugarcane is a high-yielding crop that requires significant amount of nutrients, since mineral elements comprise about $3 \%$ to $5 \%$ of its dry matter. Sugarcane yields about 25 to 40 t ha $^{-1}$ of dry matter in typical average Brazilian farming conditions, of which about $60 \%$ to $70 \%$ are removed from fields as stalks. Thus, sugarcane fertilization may be undertaken considering that significant amount of nutrients are exported with the harvested parts. Information gathered by several authors has shown that the above-ground portion of sugarcane contains the following nutrients for each $100 \mathrm{t}$ of stalks produced: N, 100 to $154 \mathrm{~kg}, \mathrm{P}_{2} \mathrm{O}_{5}, 15$ to 25 $\mathrm{kg}, \mathrm{K}_{2} \mathrm{O}, 77$ to $232 \mathrm{~kg}$, and S, 14 to $49 \mathrm{~kg}$ (RAIJ et al., 1997; FRANCO et al., 2008a; MOURA FILHO et al., 2008; ROSSETTO et al., 2008a).

Among Brazilian crops, sugarcane is third in fertilizer consumption, after soybean and corn. In $2007 / 2008$, cultivation of about $8.3 \times 10^{6}$ hectares of sugarcane required about $3.4 \times 10^{6} \mathrm{t}$ of NPK, which is $13.8 \%$ of the Brazilian use of fertilizers (ANDA, 2007). Sugarcane, however, receives a relatively small amount of fertilizers - mean 408 $\mathrm{kg} \mathrm{ha}^{-1}$ of NPK (ANDA, 2007) - when the amount of plant material (mean stalk yield of $77 \mathrm{t} \mathrm{ha}^{-1}$ ) and its long growth cycle are taken into account. Recommended nutrient doses for sugarcane in Brazil, especially N, are generally lower than those applied in many other countries with similar yields (HARTEMINK, 2008). The contribution of biological nitrogen fixation (BNF) is one of the probable reasons explaining why less nitrogen is used in
Brazilian sugarcane. Nutrient recycling, common in the sugarcane industry, is also important for rational fertilizer use; solid and liquid residues, such as filter cake, ash, trash, and especially vinasse, are returned to fields.

Much experience from several research centers has been gained on sugarcane fertilization and nutrition for soil conditions in traditional Brazilian producing regions. Recent reviews on this theme include the publications of CANTARELLA et al. (2007), KORNDÖRFER (2008), MELLIS et al. (2008), QUAGGIO (2008), ROSSETTO et al. (2008a, b, c, d) and VITTI et al. (2008a, b). This text aims to highlight some aspects about sugarcane fertilization for which additional research is needed to face the challenges of increasing competitiveness in the biofuel sugarcane industry.

\section{LIMING AND GYPSUM APPLICATION}

Brazilian soils are generally acid, which does not favor root growth because the exchangeable aluminum content is higher and several other nutrients are less available. Limestone is used in agriculture to correct soil acidity and to provide calcium and magnesium, which are essential for plants. Limestone requirements vary according to each crop; different criteria are applied in Brazil for establishing sugarcane limestone needs. In São Paulo, SPIRONELLO et al. (1997) have recommended raising the base saturation (V) to $60 \%$ of the cation exchange capacity (CEC) and to use dolomitic limestone when the level of exchangeable magnesium becomes lower than $5 \mathrm{mmol}_{\mathrm{c}} \mathrm{dm}^{-3}$. In 
the Cerrado region, the aim has been to raise $\mathrm{V}$ to 50\% (SOUSA, 2002). Other criteria in use involve calculating the dose of limestone to neutralize exchangeable aluminum and raise the percentage of exchangeable calcium to $30 \mathrm{mmol}_{\mathrm{c}} \mathrm{dm}^{3}$ (BENEDINI, 1988; PENATTI, 1993; KORNDÖRFER et $a l ., 1999)$. In many sugarcane cultivated soils the exchangeable aluminum content is low, so that the calcium content is more relevant for defining the dose of limestone in this last criterion. On the other hand, several authors have suggested that sugarcane calcium requirements are met with soil contents around 7 to $8 \mathrm{mmol}_{\mathrm{c}} \mathrm{dm}^{3}$ (ZAMBELLO JR., 1981; MARINHO, 1983).

Although many studies have been conducted on acidity correction in sugarcane, there is no consensus on this topic (QUAGGIO, 2008). Sugarcane is relatively tolerant to soil acidity and the presence of aluminum (MARINHO, 1983; ROSSETTO et al., 2004). QUAGGIO and RAIJ (2008) gathered data from papers published in Brazil showing that this crop responds little to liming of soils with base saturation above $25 \%$ of the CEC, which equates with a $\mathrm{pH}$ rate of $4.5 \mathrm{in}$ calcium chloride. A point to consider is that sensitivity to soil acidity depends on the variety. Several studies have been made of rustic varieties - which are prevalent in farms such as SP70-1143; furthermore, micronutrients were not added in most liming trials, which may have limited the response to limestone (RAIJ, 2008; QUAGGIO, 2008). In some cases, limestone need may have been underestimated.

Roots do not develop well in soils with low subsurface calcium content, because calcium is poorly mobile in plant phloem; thus, it should be made available close to the root growth area. Liming may provide calcium to subsoil layers; in this case the dose of limestone should be higher than that calculated to neutralize acidity in the superficial layer.

Gypsum has been widely employed in sugarcane farming to raise subsoil $(20-60 \mathrm{~cm})$ calcium content and to decrease aluminum activity in soil solution; this improves the chemical environment for root development. Gypsum is also a source of sulfur; combining limestone and gypsum may yield better results for sugarcane crops than ap- plying each one singly (MORELLI et al., 1987, 1992; PERNATTI, 1993). Limestone, which is less soluble than gypsum, is more effective in the superficial layer, while gypsum acts in the subsoil because of calcium sulphate mobility in soil solutions. Therefore, gypsum requirements are based on the chemical features of the subsurface soil layer (20 to $40 \mathrm{~cm}$ ): gypsum application should be done whenever exchangeable calcium levels become lower than $4 \mathrm{mmol}_{\mathrm{c}} \mathrm{dm}^{-3}$ and aluminum saturation raises above $40 \%$. Since there is no reference sulphate adsorption index, the dose of gypsum is calculated by taking into account the clay content in the 20 to $40 \mathrm{~cm}$ layer: gypsum, in t $\mathrm{ha}^{-1}=6 \mathrm{x}$ clay, in $\mathrm{g} \mathrm{kg}^{-1}$ (RAIJ et al., 1997). SOUSA and LOBATO (2002) applied a 7.5 factor instead of 6 in the Cerrado region.

Liming and gypsum application are generally done when the sugarcane plantation is reformed. Given that soils tend to acidify with time due to nitrogen fertilizers and losses by leaching, soils may become excessively acid at the end of a cycle. Although response of sugarcane to liming is small, soil reacidification may decrease the yield and lower the lifetime of ratoons. To overcome this problem, QUAGGIO and RAIJ (2008) recommend reapplying limestone and gypsum in ratoons to raise the base saturation to $60 \%$ whenever the base saturation in the surface soil layer in ratoons becomes lower than 40\% and soil analysis indicates a need for gypsum. RAIJ (2008) noted that several published reports have indicated responses to gypsum at higher doses than those currently recommended. This author, therefore, has suggested that subsoil fertility should also be taken into account, and that long-term studies should be carried out to investigate higher gypsum rates than those currently employed. The effects of an improved chemical environment for subsoil root growth as a result of combining liming and gypsum application may be interesting, especially in poor soils and in areas with dry winters, to which sugarcane crops tend to move.

Calcium silicates or calcium and magnesium silicates not only provide silicon but also correct soil acidity, and may eventually replace limestone in sugarcane crops. Replacing limestone with sili- 
cates is not always economically feasible because the latter are more expensive. Furthermore, ordinary silicates contain little magnesium, which may limit the use of these materials in soils lacking this element. On the other hand, there may be advantages in using silicates for sugarcane planted in silicon-deficient soils. Although this element is not a plant nutrient, several reports in the literature have shown beneficial effects when applying it to sugarcane crops (KORNDÖRFER, 2008). Large amount of accumulated silicon in sugarcane plants increase the thickness of cell walls and alter the plant architecture, raising the tolerance to certain disease and pests, and to drought and lodging. In several countries, application of silicon is recommended based on foliar analysis (KORNDÖRFER, 2008).

\section{FERTILIZATION OF SUGARCANE}

\section{Nitrogen}

Nitrogen is the most complex nutrient to manage in sugarcane fertilization, given its many interactions with soil organic matter (SOM) and several possible routes by which nitrogen may be lost in the soil-plant system. Mineralization of SOM - the main source of nitrogen for plants - depends not only on soil and SOM characteristics, but also on the climate, in particular rain and temperature, which are hard to predict. Thus, nitrogen is one of the few nutrients for which soil analysis is not taken into account for fertilizer recommendations; this increases the degree of uncertainty when defining nitrogen doses for sugarcane (CANTARELLA, 2007).

In quantity, nitrogen is the second mineral nutrient accumulated in sugarcane plants after potassium. The above-ground portion of the plant contains from 0.7 to $1.6 \mathrm{~kg}$ of nitrogen per ton of stalk; the whole plant shows a nitrogen requirement of 2.1 to $2.4 \mathrm{~kg}$ of nitrogen per ton of stalk (ORLANDO FILHO et al., 1980; TRIVELIN et al., 2002a; CANTARELLA et al., 2007). These numbers suggest that sugarcane extracts over $200 \mathrm{~kg} \mathrm{ha}^{-1}$ of nitrogen to yield $100 \mathrm{t} \mathrm{ha}^{-1}$ of stalks, of which about 90 to $110 \mathrm{~kg} \mathrm{ha}^{-1}$ are exported upon harvesting.
Generally, sugarcane plant recovery of nitrogen applied as a fertilizer is low, around 20 to 40\% as shown in most studies done with ${ }^{15} \mathrm{~N}$ (CHAPMAN et al., 1992; TRIVELIN et al., 1995, 2002b; GAVA et al., 2003; VITTI, 2003; AMBROSANO et al., 2005). These numbers are lower than those seen in grain crops (FRENEY et al., 1992; DOBERMANN, 2005). One of the reasons is that sugarcane has a long cycle, which allows it to exploit soils longer; additionally, fertilizers are applied at the beginning of growth cycles, and are subject to immobilization by SOM and/or losses. In fact, soil becomes the destination for much of the fertilizer nitrogen (20\% to 40\%), where it is incorporated into the nitrogen stock of SOM, as demonstrated in studies compiled by CANTARELLA et al. (2007).

A small percentage of accumulated nitrogen in sugarcane derives from nitrogen fertilizers - 15\% to $20 \%$ in most studies with fertilizers marked with ${ }^{15} \mathrm{~N}$ (SAMPAIO et al., 1984; TRIVELIN et al., 1995; GAVA et al., 2001b; 2003; BASANTA et al., 2002; AMBROSANO et al., 2005), suggesting that most of the absorbed nitrogen in sugarcane originates from the soil, from BNF, and to a lesser degree, from airborne solid depositions and rain, among others.

Sugarcane cultivation in Brazil is done using relatively small amounts of nitrogen fertilizers - 30 to $60 \mathrm{~kg} \mathrm{ha}^{-1}$ of nitrogen in the plant cycle, and 60 to $120 \mathrm{~kg} \mathrm{ha}^{-1}$ of nitrogen in ratoon crops (SPIRONELLO et al., 1997; PENATTI et al., 1997; CANTARELLA et al., 2007). Nitrogen rates are generally higher than $120 \mathrm{~kg} \mathrm{ha}^{-1}$ and, in some cases, may reach $200 \mathrm{~kg} \mathrm{ha}^{-1} \mathrm{~N}$ or more (DONZELLI, 2005; GARCIA et al., 2003; RICE et al., 2006).

The amount of nitrogen fertilizer applied in Brazilian sugarcane crops is generally equal to or lower than the amount exported with stalk harvesting and trash burning. Nevertheless, sugarcane has been cultivated continuously for decades - or even for over a century in certain regions - without yield loss, apparent soil degradation, or marked SOM depletion (BODDEY, 1995). In Brazil, this has been seen as indirect evidence that BNF has a relevant role in sugarcane nitrogen nutrition (URQUIAGA et al., 1992; BODDEY et al., 2003).

Since DOBEREINER'S (1961) pioneering work, isolating $\mathrm{N}_{2}$-fixating bacteria in sugarcane 
roots, several diazotrophic bacteria have been associated with this crop, particularly those of the Glucanoacetobacter, Herbaspirillum, and Burkholderia genuses, which have been detected in sugarcane stalks, leaves, roots, and vascular system (BALDANI et al., 1997; REIS et al., 2004; CABALLERO-MELLADO et al., 2004; PERIN et al., 2006).

Diazotrophic bacteria may promote plant growth not necessarily associated with BNF, but with phytohormone production, increased plant enzyme activity, and pathogen control (JAMES, 1997; SEVILLA et al., 2001; PINON et al., 2002; MARQUES Jr. et al., 2008). URQUIAGA et al., (1992), however, using ${ }^{15} \mathrm{~N}$ to measure nitrogen balance in long-term studies of sugarcane, have shown that $60 \%$ to $70 \%$ of accumulated nitrogen originated from BNF in some varieties. The amount of fixated nitrogen reached 170 to $210 \mathrm{~kg} \mathrm{ha}^{-1}$ of nitrogen. However, the contribution of BNF in the majority of published studies has been below $30 \%$ of absorbed nitrogen, sometimes associated with specific sugarcane varieties (OLIVEIRA et al., 2002, 2003, and 2006). Surveys using the $\delta^{15} \mathrm{~N}$ technique in several countries have shown a BNF contribution ranging from $0 \%$ to $70 \%$, with $30 \%$ as the mean value (YONEYAMA et al., 1992; POLIDORO et al., 2001).

Practical implications of BNF for sugarcane plant nutrition are controversial. It is thought that BNF contribution is relevant, albeit not constant, under Brazilian conditions. However, studies in Australia, South Africa, and Spain have suggested that BNF is not a significant source of nitrogen for sugarcane in those countries (BIGGS et al., 2002; THORBURN et al., 2003; HOEFSLOOT et al., 2005; TEJEDA et al., 2005), although nitrogen fixating bacteria have been found in fields (BIGGS et al., 2002; HOEFSLOOT et al., 2005).

There are several reasons why BNF may not work properly. Application of nitrogen fertilizers can cause a reduction in microorganism numbers and in the fixating capability of diazotrophic bacteria (FUENTES RAMIREZ et al., 1999; REIS et al., 2000; KENNEDY et al., 2004). BNF also decreases in the dry season (BODDEY et al., 2003), which usually occurs when most of the ratoons start grow- ing in Southwest Brazil. Furthermore, interaction between diazotrophic bacteria and genotypes is relevant for successful BNF (URQUIAGA et al., 2003; MUNOZ-ROJAS, 2003; OLIVEIRA et al., 2006).

Inoculating diazotrophic bacteria in sugarcane plants has not been proven effective to raise BNF in field conditions because there already is an established diazotrophic bacteria community in sugarcane plantations. Furthermore, the production of an inoculant with diazotrophic bacteria for sugarcane has been hindered by the fact the several species and strains can fix $\mathrm{N}_{2}$ from the atmosphere and it is not clear which one is the main contributor to NBF (BODDEY et al., 2003). Recent promising results have been obtained by inoculating a combination of five diazotrophic species rather than single species (OLIVEIRA et al., 2002, 2003, 2006; REIS et al., 2008), which opens the possibility of raising BNF in sugarcane. Additional studies are still required before recommending diazotrophic bacteria inoculation in field conditions. Partial replacement of nitrogen fertilizers may result in economic gains and an improved energy balance for producing ethanol from sugarcane.

The traditional sugarcane manual harvesting method after burning of trash is gradually being replaced by mechanical harvesting without setting fire to the crop (known as green cane) in order to reduce harvesting costs and to meet regulatory restrictions against plantation burning. Soils, therefore, now remain covered by a thick layer of trash containing from 6 to $18 \mathrm{t} \mathrm{ha}^{-1}$ of dry matter (mean $14 \mathrm{t} \mathrm{ha}^{-1}$ in the Central-Southern region). Trashing increases nutrient recycling, especially for nutrients that are volatized during burning, such as nitrogen and sulfur. The presence of trash implies in changing fertilizing practices, in particular for nitrogen. Trash makes it difficult to incorporate fertilizers into soil, a common practice for fertilizing ratoons after harvesting and burning. Nitrogen fertilizers applied over trash increases the risk of temporary nitrogen immobilization by microorganisms that decompose plant residues (HAYSON et al., 1990), and may result in significant nitrogen losses due to volatilization of $\mathrm{NH}_{3}$ if urea - which represents $60 \%$ of nitrogen sources in 
the market - is employed. Losses of $\mathrm{NH}_{3}$ may reach from $20 \%$ to $40 \%$ or more for nitrogen applied over sugarcane trash, according to some Brazilian studies (CANTARELLA et al., 1999; VITTI et al., 2002, COSTA et al., 2003) and studies in other sugarcane producing countries (PRAMMANEE et al., 1989; DENMEAD et al., 1990; FRENEY et al., 1992). Adding urease inhibitors to urea may decrease $\mathrm{NH}_{3}$ losses, but the degree of loss depends also on factors such as the temperature, soil moisture, and rainfall (CANTARELLA et al., 2008). CANTARELLA et al. (2007) and VITTI et al. (2008b) have described other possibilities for reducing $\mathrm{NH}_{3}$ losses in sugarcane fertilization.

The need for altering nitrogen rates for sugarcane according to the presence of trash is not clear. Increased nitrogen recycling with trash may raise the stock of organic nitrogen in soils in the long term; however, studies in Brazil, Australia and South Africa have suggested that such changes are slow and usually restricted to soil depths of up to $10 \mathrm{~cm}$ (GRAHAM et al., 1999, 2000, 2002; THORBURN et al., 2000; LUCA, 2002). On the other hand, sugarcane takes up only $5 \%$ to $10 \%$ of the nitrogen present in the trash (40 to $80 \mathrm{~kg} \mathrm{ha}^{-1}$ of nitrogen) in the season following trash deposition (NG KEE KWONG et al., 1987; CHAPMAN et al., 1992; GAVA et al., 2003; VITTI et al., 2008c).

In the short term, fertilizing nitrogen doses in unburnt harvested areas may be higher than in burnt areas because of nitrogen demand by microorganisms for breaking down trash, as well as higher stalk production due to increased water availability (OLIVEIRA et al., 1994), although stalk yield may not always be higher in green cane areas (THORBURN et al., 1999; GAVA et al., 2001a; BASANTA et al., 2003). Nitrogen in a soil-plant system must reach a new equilibrium in areas managed with surface trash, after which fertilizing nitrogen doses may decrease because of an increased stock and cycling of this nutrient in soil (MEIER et al., 2002). THORBURN et al. (2002) used a simulation model and estimated that the sugarcane nitrogen response in Australia would only stabilize after 30 to 40 years. However, rainfall in the study area (950 mm a year) was lower than that in most sugarcane cultivated areas in Brazil.
As in Australia, there is no consensus in Brazil on nitrogen rate changes in green cane. However, nitrogen rates applied in areas not burnt during eight to ten years in several sugar mills in São Paulo state have decreased 20\% or more. Detailed studies are required for calculating nitrogen fertilization in unburnt areas, given its economic and environmental implications.

\section{Phosphorus, Potassium and Sulfur}

Phosphorus takes part in complex physicalchemical soil reactions. It is strongly retained by iron and aluminum oxides in acid soils, and precipitates as calcium phosphate in alkaline soils. Therefore, the concentration of phosphorus in soil solutions is usually very low. The efficiency of phosphate fertilization is usually small in that generally $10 \%$ to $30 \%$ of applied phosphorus is absorbed by plants during their growth cycle; the remaining phosphorus is immobilized in soil, part of which may be used in subsequent cycles.

Most Brazilian soils are originally poor in phosphorus. Thus, sugarcane responses to applications of this element are high, especially in the plant cane cycle. The plant requirement ranges from 10 to $40 \mathrm{~kg} \mathrm{ha}^{-1}$ of $\mathrm{P}_{2} \mathrm{O}_{5}$ for each 100 tons of cane, as compiled by ROSSETTO et al. (2008a). Phosphorus fertilizer is used in larger amount in Brazil compared to most of the other cane producers. The mean doses are 120 and $30 \mathrm{~kg}$ ha-1 of $\mathrm{P}_{2} \mathrm{O}_{5}$ for cane plant and cane ratoon crops, respectively (DONZELLI, 2007; ROSSETTO et al., 2008a). Corresponding rates of $\mathrm{P}_{2} \mathrm{O}_{5}$ in $\mathrm{kg} \mathrm{ha}^{-1}$ for plant and ratoon crop values are 58 and 57 in Australia(DONZELLI, 2007, HARTEMINK, 2008); 60 and 60 in Mexico, and 150 and 75 in Costa Rica, respectively (ROSSETTO et al., 2008a).

Phosphate fertilization is recommended based on available $\mathrm{P}$ content in the soil. Phosphorus doses for plant cane range from 40 (for soils with a high phosphorus content) to $180 \mathrm{~kg} \mathrm{ha}^{-1}$ of $\mathrm{P}_{2} \mathrm{O}_{5}$ for very low P soils (SPIRONELLO et al., 1997) in São Paulo state. Research results show that in many cases, phosphorus applied at planting supplies $\mathrm{P}$ for the full cycle; little or no response is seen when this nutrient is applied to ratoons (BOLSANELLO 
et al., 1993, KORNDÖRFER, 2004). Nevertheless, phosphorus fertilization of ratoons may increase the stalk yield in poorly or non-fertilized areas in the plant crop cycle (WEBER et al., 2002) in soils with low levels of available phosphorus (VITTI, 2002) or when soil acidity increases across the years and decreases phosphorus availability (DEMATTÊ, 2005).

Recommended doses of phosphorus for ratoons in São Paulo state are much lower than those for plant crops: $30 \mathrm{~kg} \mathrm{ha}^{-1}$ of $\mathrm{P}_{2} \mathrm{O}_{5}$ for soils with low or very low phosphorus content. Phosphate fertilizers are not indicated for soils with medium or high phosphorus content (SPIRONELLO et al., 1997). Lower doses of phosphorus applied to ratoons reflect experimental data showing limited responses to phosphate fertilization after the first harvest. However, removal of 0.25 to $0.40 \mathrm{~kg}$ of $\mathrm{P}_{2} \mathrm{O}_{5}$ per ton of dry matter harvested may impoverish the soil across the crop cycle, as DEMATTÊ (2005) has shown, which underlines the importance of replacing at least part of the $\mathrm{P}$ exported in ratoons.

Highly water-soluble sources are indicated for applying phosphorus in planting furrows, as demonstrated in pioneer studies of ALVAREZ et al. (1965). Reactive phosphates and thermophosphates may partially or fully replace these sources of soluble phosphates in medium or high phosphorus content soils (CANTARELLA et al., 2002; ROSSETTO et al., 2002). These options may be advantageous in specific situations because reactive natural phosphates are inexpensive, and thermophosphates contain magnesium and micronutrients, besides silicon, which sugarcane absorbs in significant amounts.

In soils with low or very low phosphorus, which limit sugarcane production, high P fertilizer rates broadcast and incorporated into the soil (phosphatation) is an option for totally or partially substitute for the usual furrow application in order to rapidly raise soil fertility and increase yields (ROSSETTO et al., 2002, VITTI, 2002). Low watersoluble phosphates are appropriate for phosphatation because the thorough mixture and increased contact with soil facilitate the solubility of these P sources (KORNDÖRFER, 2004).
Significant amounts of phosphorus may be recycled in sugarcane crops by using organic waste, which reduces the need for mineral fertilizers. Filter cake is produced in an average of $30 \mathrm{~kg}$ per ton of crushed cane and contains $1 \%$ to $3 \%$ phosphorus. Practically the entire cake filter produced in sugar mills is reused in agricultural areas in its natural state or by composting (COLETI et al., 1986). For calculation purposes, 50\% of phosphorus in filter cake is available for plants in the short term (SPIRONELLO et al., 1997).

Potassium is the nutrient extracted in the highest amounts by sugarcane plants; therefore, significant responses to potassium fertilization are expected, especially in low $\mathrm{K}$ soils, as has been demonstrated in recent reviews by KORNDÖRFER and OLIVEIRA (2005) and ROSSETTO et al. (2008c).

Managing potassium fertilization is relatively easy compared to nitrogen and phosphate because potassium interacts less with soil mineral and organic components. Exchangeable potassium content in soil is a good indicator of potassium needs, and may be used as a parameter for fertilizer requirements together with expected yield, which is relevant for nutrients that accumulate significantly in plants (RAIJ, 1974; ORLANDO FILHO et al., 1980, RAIJ et al., 1997; KORNDÖRFER et al., 1999, ROSSETTO et al., 2004; 2008c). Recommended doses for the plant cane cycle for soils with very low potassium content $\left(<0.8 \mathrm{mmol}_{c}\right.$ $\mathrm{dm}^{-3}$ ) in São Paulo state range from 100 to $200 \mathrm{~kg}$ $\mathrm{ha}^{-1}$ of $\mathrm{K}_{2} \mathrm{O}$, depending on expected yield. Corresponding doses for soils with medium potassium content (1.6 to $3.0 \mathrm{mmol}_{\mathrm{c}} \mathrm{dm}^{-3}$ ) are 40 to $80 \mathrm{~kg}$ $\mathrm{ha}^{-1}$. Potassium fertilization is not recommended for soils containing over $6 \mathrm{mmol}_{\mathrm{c}} \mathrm{dm}^{-3}$. Doses range from 30 to $150 \mathrm{~kg} \mathrm{ha}^{-1}$ of $\mathrm{K}_{2} \mathrm{O}$ in ratoon cycles as a function of nutrient availability in soils and yield goals (SPIRONELLO et al., 1997). Medium potassium doses applied in sugarcane (plant cane and ratoons, respectively) in some countries are: 120 and $145 \mathrm{~kg} \mathrm{ha}^{-1}$ of $\mathrm{K}_{2} \mathrm{O}$ in Australia; 175 and 150 $\mathrm{kg} \mathrm{ha}^{-1}$ of $\mathrm{K}_{2} \mathrm{O}$ in Costa Rica (ROSSETTO et al., 2008c). In Florida (US), doses range from 0 to 280 $\mathrm{kg} \mathrm{ha}^{-1}$ of $\mathrm{K}_{2} \mathrm{O}$ in plant crops to 0 to $170 \mathrm{~kg} \mathrm{ha}^{-1}$ of $\mathrm{K}_{2} \mathrm{O}$ in ratoons (RICE et al., 2006); in Louisiana 
(US), doses are lower, at 55 and $67 \mathrm{~kg} \mathrm{ha}^{-1}$ of $\mathrm{K}_{2} \mathrm{O}$ for plant and ratoon crops respectively (LEGENDRE, 2001), which reflects potassium supplies in different soils.

Potassium is usually applied once in the plant furrow or soon after harvesting, over ratoons, during the agricultural year. However, leaching losses may occur in low CEC sandy soils, especially in the plant cane cycle because of initial slow crop growth. Potassium fertilization may be split under such conditions. A further benefit of $\mathrm{K}$ splitting in soils with a sandy texture is to avoid damage to sprouting due to excess salt in the plantation furrow (KORNDÖRFER, 2005).

Potassium chloride is the most commonly used potassium source in sugarcane; its cost is lower compared to other potassium fertilizers, it is water-soluble, and the nutrient is readily available for plants. Vinasse is also an important source of potassium in ethanol-producing companies; significant amounts of nutrients may be recycled and mineral fertilizers can be replaced in parts of the area (see MUTTON et al, in this book). Vinasse is a byproduct of ethanol or cachaça fermentation and is generated in large amounts (between 800 and $199 \mathrm{~L}$ per ton of cane when ethanol is produced from cane juice or from molasses, respectively); it contains 0.8 to $3.8 \mathrm{~g} \mathrm{~L}^{-1}$ of $\mathrm{K}_{2} \mathrm{O}$ (mean $-2.0 \mathrm{~g} \mathrm{~L}^{-1}$ ), depending on the material used for fermentation (ROSSETTO et al., 2008c). An application of 100 $\mathrm{m}^{3} \mathrm{ha}^{-1}$ yields from 80 to $380 \mathrm{~kg} \mathrm{ha}^{-1}$ of $\mathrm{K}_{2} \mathrm{O}$ generally more than enough to provide crop needs.

In São Paulo state, the State Environmental Agency (Companhia Tecnológica de Saneamento Ambiental or CETESB) defined the Technical Standard P4231 (2005) to regulate the dose of vinasse that can be applied to the fields. This is calculated such that the amount of exchangeable potassium in the 0 to $80 \mathrm{~cm}$ soil layer does not exceed $5 \%$ of the soil cation exchange capacity (CEC). In soils with this CEC saturation level, potassium provided by vinasse should be restricted to replacing the only the amount of $\mathrm{K}$ that the sugarcane plant has extracted, which is estimated at $185 \mathrm{~kg} \mathrm{ha}^{-1}$ of $\mathrm{K}_{2} \mathrm{O}$ (KORNDÖRFER, 2005).

Luxury potassium consumption - absorption of nutrients beyond the necessary amount for plant function - may occur in fertile soils or those fertilized with high doses of potassium or vinasse. In this case, accumulated potassium in sugarcane plants may reach values well beyond the mean values mentioned above: 0.77 to $2.32 \mathrm{~kg}$ of $\mathrm{K}_{2} \mathrm{O}$ per ton of stalk. For example, FRANCO et al. (2008a,c) measured $\mathrm{K}$ uptake in plant cane grown in a high available K Dystrophic Red Latosol in Jabotiacabal, and found $589 \mathrm{~kg} \mathrm{ha}^{-1}$ of $\mathrm{K}_{2} \mathrm{O}$ in the above-ground parts and $659 \mathrm{~kg} \mathrm{ha}^{-1}$ of $\mathrm{K}_{2} \mathrm{O}$ in the whole plant including its underground portion - at harvesting time, with a stalk yield of about de $146 \mathrm{t} \mathrm{ha}^{-1}$.

High vinasse rates generally delay cane maturity by stimulating vegetative growth, which decreases the sucrose content in stalks (SILVA et al., 1976; ORLANDO FILHO et al., 1995), thus affecting raw material quality for industrialization. However, this effect appears not to be associated with excess potassium, but rather with excessive amount of other nutrients, such as nitrogen, or with organic matter in vinasse, since luxury potassium consumption generally does not affect sugar or sucrose concentration in syrup when provided as a mineral fertilizer (ORLANDO FILHO et al., 1980; CHALITA, 1991). Luxury potassium absorption increases ash content, which negatively affects sugar crystallization, thus decreasing the industrial yield. On the other hand, ash may favorably affect ethanol production by serving as a source of nutrients for yeast (KORNDÖRFER, 2005).

Some distilleries have areas for occasionally dumping vinasse ("sacrifice" areas) when field application is not possible and that may accumulate high amounts of K. Excess soil potassium in such areas may be removed by cultivating sugarcane as long as the soil has not become saline or the extremely high $\mathrm{K}$ does not affect plant growth due to imbalances with other nutrients. Because of luxury potassium consumption, large amounts are absorbed from the soil and may be removed in cane stalks, which generally contain over half of the potassium content in the above-ground portion of plants, as the crop is harvested and K exported from the fields (ROSSETTO et al., 2008c).

The amount of sulfur extracted by sugarcane is relatively small ( 0.2 to $0.5 \mathrm{~kg}$ per ton of stalk), 
depending on the variety, soil type and fertilization (RAIJ and CANTARELLA, 1997; COLETI et al., 2002; RAIJ et al., 2006; TASSO Jr. et al., 2007; ViTti et al., 2008a). Sulfur has been neglected in studies of sugarcane in Brazil. The effect of sulfur on sugarcane yield is often indirectly inferred in works aimed at investigating gypsum or fertilizing sources of nitrogen and phosphorus that contain sulfur (CANTARELLA et al., 2007). Several authors have suggested that sugarcane responses attributed to other elements in fertilizers, may be due to sulfur (VITTI et al., 1992). For example, VITTI et al. (1988), citing MALAVOLTA et al. (1982), have considered that part of stalk production variations from different sources of phosphorus were due to the presence or absence of sulfur in the fertilizer. Similarly, VITTI et al. (2005) have noted that sulfur-containing nitrogen sources (ammonium sulfate, liquid fertilizer containing vinasse) resulted in higher stalk yields compared to sulfur-free nitrogen sources (urea, ammonium nitrate), although the advantage of ammonium sulfate over urea may also have been due to lower $\mathrm{NH}_{3}$ losses by volatilization. There may also be synergy between nitrogen and sulfur in plants. BOLOGNA-CAMPBELL (2007), in a study using ${ }^{34} \mathrm{~S}$, noted that nitrogen fertilization increased sulfur uptake by sugarcane. The opposite has also been observed. VITTI et al. (2005), in a study using ${ }^{15} \mathrm{~N}$, showed that nitrogen was used more efficiently in treatments containing ammonium sulfate compared with those containing urea, although the effect may be partially attributed to $\mathrm{NH}_{3}$ losses, as mentioned above.

ESPIRONELLO et al. (1987) observed small responses to sulfur as a nutrient in 2- to 4-year long studies in four sites. Differences were significant in only one site, but there was a trend toward $\mathrm{S}$ response in all of them, which suggested that experimental errors may make small yield increments unnoticed when using sulfur.

Recommended sulfur rates for sugarcane are low. VITTI et al. (1992) suggest applying $30 \mathrm{~kg}$ $\mathrm{ha}^{-1}$ of sulfur for the cane plant crop and $15 \mathrm{~kg} \mathrm{ha}^{-1}$ of sulfur per year for ratoons. For the whole cane cycle between 50 and $60 \mathrm{~kg} \mathrm{ha}^{-1}$ of sulfur should suffice (VITTI, 2002; DEMATTÊ, 2005).
The frequent application of gypsum and residues of sugar and ethanol production, common in the southwest region in Brazil, probably can supply the $\mathrm{S}$ requirements of most sugarcane plantations. Nevertheless, S deficiencies may occur where gypsum is not applied or where organic residues are not returned to the fields, such as in areas distant from the mill or belonging to independent cane suppliers to the industry, or in sites fertilized with concentrated NPK formulations, especially in sugarcane plantations harvested after burning, in which part of the plant sulfur is lost to the atmosphere rather than recycled in the field (CANTARELLA et al., 2007; VITTI et al., 2008a).

\section{Micronutrients}

Micronutrient extraction by the sugarcane plant is relatively small, notwithstanding the large volume of plant material produced. The aboveground portion of the crop accumulates about 50 $\mathrm{g}$ of molybdenum, $500 \mathrm{~g}$ of boron, copper or zinc, from 1,000 to $4,000 \mathrm{~g}$ of manganese, and from 4,000 and 10,000 g of iron (ORLANDO FILHO, 1983; FRANCO et al., 2008c; MOURA FILHO et al., 2008) to yield $100 \mathrm{t}$ of stalks.

Few studies on micronutrients in sugarcane have been published in Brazil. Responses to micronutrients in sugarcane have been infrequent, as shown in the pioneering work of ALVAREZ and WUTKE (1963), ESPIRONELO (1972), ALVAREZ et al. (1979), and others. Sugarcane is in fact thought to respond poorly to micronutrients, especially in the Southwest region, as demonstrated in reviews by ORLANDO FILHO et al. (2001) and MELLIS et al. (2008). It is also likely that many studies in which micronutrients had no effect on plants may not have been published.

Part of the reason for poor sugarcane responses to micronutrients is that for many years this crop was planted in the best soils of the Southwest region. Furthermore, organic residues from sugar mills and distilleries were recycled. Thus, micronutrient fertilization of sugarcane in this region has been infrequent. On the other hand, micronutrient deficiencies are known, especially of copper, zinc and boron in low-fertility soils on 
the coastal flat lands of the Northeastern region (MARINHO, 1981).

Increased stalk yields due to micronutrient applications have been reported sporadically in specific sites. Responses to boron were seen in studies by ALVAREZ and WUTKE (1963), Alvarez (1984), and in unpublished work cited by ORLANDO FILHO et al. (2001). MARINHO and ALBUQUERQUE (1981) and other authors have described responses to copper in São Paulo (ALVAREZ, 1984) and in sandy soils in the Northern area of Rio de Janeiro, São Paulo and Mato Grosso do Sul states (ORLANDO FILHO et al., 2001). AZEREDO and BOLSANELLO (1981) obtained increased stalk yields by adding $5 \mathrm{~kg} \mathrm{ha}^{-1}$ of manganese in field trials in Rio de Janeiro, Espirito Santo, and Minas Gerais states. Other studies reporting responses to manganese have been conducted in the state of Pernambuco (ORLANDO FILHO et al., 2001). Zinc is the micronutrient for which favorable responses of sugarcane have been most frequently reported. MARINHO and ALBUQUERQUE (1981) found increased stalk yields in Northeastern Brazil, and ALVAREZ (1984), CAMBRIA et al. (1989) and ORLANDO FILHO et al. (2001) reported such increases in São Paulo and Mato Grosso do Sul. Recent studies showing responses to zinc applied in sugarcane plantations in the state of São Paulo include those by FRANCO et al. (2008c) and MELLIS. ${ }^{1}$

Molybdenum is the nutrient extracted in the smallest amounts by sugarcane and few studies with this element are available. ALVARES and WUTKE (1963) and ALVAREZ et al. (1979) found responses to molybdenum in trials carried in São Paulo many decades ago. MELLIS and ALVES ${ }^{2}$ have recently shown increased cane yields by adding molybdenum. Soil depletion of Mo, increased yields obtained with new varieties and improved crop management and the larger nitrogen requirements associated it may explain these last results.

\footnotetext{
1 MELLIS, E. V. Instituto Agronômico, Campinas, SP. Personal communication. Data from the ongoing micronutrient trial. Network in São Paulo state.

2 ALVES, Bruno Rodrigues. Embrapa Agrobiologia, Seropédica, RJ, Personal communication.
}

Favorable responses to iron are improbable in the acid Brazilian soils. Chloride is applied in large quantities with potassium and, thus, there are no reports of chloride deficiencies in sugarcane.

Many authors have associated sugarcane response to micronutrients with diagnosis of micronutrient by soil analysis. Critical, albeit preliminary, levels of micronutrient availability in soils have been suggested. Responses to copper fertilization are expected in soils with copper levels below $0.6 \mathrm{mg} \mathrm{dm}^{-3}$ (SANTOS, 1980) or $0.25 \mathrm{mg} \mathrm{dm}^{-3}$ (MARINHO, 1981) in soils (copper extracted by the Mehlich-1 solution). Copper in sugarcane is recommended in São Paulo with soil copper concentration below $0.2 \mathrm{mg} \mathrm{dm}^{-3}$ in DTPA extract (SPIRONELLO et al., 1997). MARINHO and ALBUQUERQUE (1981) have suggested a 0.5 mg dm${ }^{-3}$ limit for zinc (Mehlich-1); this same limit is used in the state of São Paulo in DTPA extracts (SPIRONELLO et al., 1997). MALAVOLTA (1990), cited by ORLANDO FILHO et al. (2001), has suggested concentration limits for several sugarcane soil nutrients, defined in studies of various crops.

ORLANDO FILHO et al. (2001) compiled data in the literature about critical and adequate foliar concentration ranges for sugarcane micronutrients, although foliar analysis is little used in Brazilian sugarcane plantations because results vary widely.

Several experiments that reported low responses to micronutrients were conducted a long time ago; thus, micronutrient requirements for high yields needs to be reassessed. Long-term sugarcane extraction and export of these elements has impoverished soils in cultivated areas. On the other hand, new more productive and demanding sugarcane varieties have been introduced; furthermore this crop is being grown in poorer soils, where nutrient deficiencies are more likely to occur.

Small yield increases are not always considered as statistically significant; if consistent, however, they deserve attention. Thus the need for networked trials to establish more clearly the critical micronutrient levels in soils and leaves. Short-term or single crop studies may not be sufficient. FRANCO et al. (2008b), for example, ap- 
plied zinc to plant cane and found increased yields only in the ratoons.

Recent results have suggested that molybdenum deserves further attention. Molybdenum has an important role in biological nitrogen fixation, and may be relevant for nitrogen fixing endophytic microorganisms in sugarcane.

\section{ENVIRONMENTAL ASPECTS OF FERTILIZATION}

\section{Nitrogen and other nutrient losses to the environment}

Volatilization of $\mathrm{NH}_{3}$ may result in significant loss of fertilizer nitrogen - especially urea - as discussed above.

Contamination of underground and surface water by nitrates from nitrogen fertilizers has become an environmental issue in a few regions of the world; nitrates may compromise the quality of drinking water or result in eutrophication of lakes, estuaries and vast areas in seas (LAGREID et al., 1999; HOWARTH, 2006; SCAVIA, 2006). Available data has suggested that $\mathrm{NO}_{3}^{-}$losses by leaching in sugarcane are negligible with current management practices (CANTARELLA et al., 2007); these losses may be relevant in other parts of the world where higher nitrogen doses are employed (PRASERTSAK et al., 2002).

Losses by denitrification produce mainly $\mathrm{N}_{2}$ and $\mathrm{N}_{2} \mathrm{O}$. The assessment of such losses is done with great uncertainties because of methodological limitations. Losses due to denitrification are generally regarded as responsible for the non-accounted portion of $\mathrm{N}$ in ${ }^{15} \mathrm{~N}$-marked nitrogen balance studies of soil-plant systems, including experimental errors. These missing $\mathrm{N}$ values attributed to denitrification range from $10 \%$ to $30 \%$ of the fertilizer-applied $\mathrm{N}$ in sugarcane (CANTARELLA et al., 2007), but may be overestimated. Increased amount of trash in green cane areas may result in higher losses by denitrification.

From the environmental point of view, emissions of $\mathrm{N}_{2} \mathrm{O}$ are the focus of global carbon balance regarding fertilizers because this gas destroys stratospheric ozone and its greenhouse effect is 296 times that of $\mathrm{CO}_{2}$. Current IPCC estimates
(2006) suggest that 1\% of fertilizer nitrogen used in agriculture is converted into $\mathrm{N}_{2} \mathrm{O}$.

Ammonia and other nitrogen-containing gases may also be lost when biomass is burned; in addition, plants with excess ammonia nitrogen or senescing plants may lose $\mathrm{NH}_{3}$ to the atmosphere (FARQUHAR et al., 1980; SCHJOERRING et al., 1998; TRIVELIN et al., 2002b).

Phosphorus is also often associated with surface water eutrophication. However, there have been few reports of excess phosphorus in sugarcane crops in Brazil, because tropical soils generally lack this nutrient and show great capacity to adsorb and retain it. Surface water contamination in these soils is mainly due to runoff erosion, since phosphorus does not move in depth. Phosphorus transportation resulting in runoff loss is uncommon because it $\mathrm{P}$ is mostly applied in plantation furrows, and little phosphorus is used on ratoons, where it is most likely to be surface-applied. Furthermore, soil conservation practices generally used in sugarcane plantations are relatively efficient for avoiding laminar flow. However, in lowlands and flood plain in Florida, US, eutrophication has been associated with $\mathrm{P}$ applied to sugarcane fields (HARTEMINK, 2008).

MUTTON et al. (in this book) discuss environmental issues due to vinasse.

Energy costs of fertilization are relevant when sugarcane is used for producing biofuels. Some authors have criticized the use of agriculture including sugarcane - for producing biofuels, arguing that added environmental costs due to greenhouse gas emissions are higher than those resulting from burning gasoline (FIELD et al., 2007; SCHARLEMANN, 2008). CRUTZEN et al. (2008) have recently stated that $\mathrm{N}_{2} \mathrm{O}$ released from soils and nitrogen fertilizers for the production of biofuels could offset the benefits derived from the reduction of $\mathrm{CO}_{2}$ emissions by replacing fossil fuels with biofuels, although in the case of sugarcane, the authors concluded that there could be a small environmental gain. However, other studies indicate that the energy balance sugarcane ethanol produced in Brazil is positive because 8 to 9 energy units are made available for each unit of fossil fuel used for producing ethanol; this 
ratio could increase as agricultural and industrial processes are improved (MACEDO et al., 2008; BODDEY et al., 2008).

Nitrogen fertilizers made of natural gas or other oil feedstock require much energy: about 53.8 MJ per kilogram of nitrogen, or about 1,400 $\mathrm{m}^{3}$ of natural gas per ton of nitrogen. BODDEY et al. (2008) calculated that about 25\% of the energy cost of field operations for producing sugarcane - including inputs, labor, machines and transportation - are due to the use of nitrogen fertilizers, notwithstanding the low dose of nitrogen: 56.7 $\mathrm{kg} \mathrm{ha}^{-1}$ nitrogen. This suggests that the reduction or the rational use of nitrogen could improve the energy balance in ethanol production.

\section{Sugarcane residues recycling}

An important point is that part of the fertilizers used for sugarcane may be replaced by agricultural residues generated in the sugar and alcohol industry. Exported products - especially sucrose and ethanol - consist of carbon, hydrogen, and oxygen, so that the mineral nutrients for producing

\section{REFERENCES}

ALVAREZ, R.; ARRUDA, H. V.; WUTKE, A. P. C. Adubação de cana-de-açúcar. X. - Experiência com diversos fosfatos (1959-1960). Bragantia, 24:1-8, 1965.

ALVAREZ, R.; WUTKE, A. C. P. Adubação da cana-deaçúcar. IX. Experimentos preliminares com micronutrientes. Bragantia, 22:647-650, 1963.

ALVAREZ, R.; WUTKE, A. C. P.; ARRUDA, H. V.; GODOY JÚNIOR, C. Adubação da cana-de-açúcar. XV. Experimentos com micronutrientes nas regiões canavieiras do Estado de São Paulo. Bragantia, 38:19-26, 1979.

ALVAREZ, V. C. Efeitos da aplicação de micronutrientes por via foliar na cultura da cana-de-açúcar. 1984. 47 f. Dissertação (Mestrado) - Unesp, Jaboticabal, 1984. AMBROSANO, E. A.; TRIVELIN, P. C. O.; CANTARELLA, H.; AMBROSANO, G. M. B.; SCHAMMASS, E. A.; GUIRADO, N.; ROSSI, F.; MENDES, P. C. D.; MURAOKA, $\mathrm{T}$. Utilization of nitrogen from green manure and mineral fertilizer by sugarcane. Scientia Agrícola, 62:534-542, 2005.

ANDA - Associação Nacional para a Difusão de Adubos. Anuário Estatístico Setor de Fertilizantes. São Paulo, Anda, 2007. 160 p. sugarcane can be at least partially recovered and recycled in agriculture. Improved means of recovering and recycling of vinasse, ash, boiler ash and filter cake, added to practices that avoid burning of sugarcane plantations, may improve the efficiency of the system for managing nutrients, with evident economic and environmental benefits.

\section{Research challenges and needs}

Topics that require further study in the context of sugarcane fertilization for ethanol production include:

a) Improving the subsoil chemical environment, especially in areas with prolonged dry seasons.

b) Long term management of sugarcane nitrogen fertilization in the presence of trash.

c) The potential of BNF for sugarcane.

d) Assessing the energy-environment balance in sugarcane fertilization, especially in the release of greenhouse gases.

e) Improving nutrient recycling in the sugar and ethanol industry.

ANDRADE, L. A. B.; CASAGRANDE, A. A.; VITTI, G. C.; PERECIN, D. Efeitos das aplicações de fritas e de fontes solúveis de boro, cobre e zinco via solo, na cultura da CAD (Saccharum spp), variedade SP 70-1143. Stab Açúcar, Álcool e Subprodutos, 13(5):21-27, 1995.

AZEREDO, D. F.; BOLSANELLO, J. Efeito de micronutrientes na produção e na qualidade de cana-de-açúcar no Rio de Janeiro, Espírito Santo e Minas Gerais (Zona da Mata - estudo preliminar). Brasil Açucareiro, 93:917,1981 .

BALDANI, J. I.; CARUSO, L.; BALDANI, V. L. D.; GOI, R. S.; DÖBEREINER, J. Recent advances in BNF with non legumes plants. Soil Biology and Biochemistry, 29:922-928, 1997.

BASANTA, M. V.; DOURADO NETO, D.; REICHARDT, K.; BACCHI, O. O. S.; OLIVEIRA, J. C. M.; TRIVELIN, P. C. O.; TIMM, L. C.; TOMINAGA, T. T.; CORRECHEL, V.; CÁSSARO, F. A. M.; PIRES, L. F.; MACEDO, J. R. Eficiência no uso de nitrogênio em relação aos manejos dos resíduos da cultura de cana-de-açúcar. In: VIII Congresso Nacional da STAB, Recife, Anais..., 8:268$275,2003$. 
BASANTA, M. V.; DOURADO NETO, D.; REICHARDT, K; BACCHI, O. O. S.; OLIVIERA, J. C. M.; TRIVELIN, P. C. O.; TIMM, L. C.; TOMINAGA, T. T.; CORRECHEL, V.; CÁSSARO, FAM.; PIRES, L. F.; MACEDO, J. R. Management effects on nitrogen recovery in a sugarcane crop grown in Brazil. Geoderma, 116:235-248, 2003.

BENEDINI, M. S. Novo conceito no uso de calcário em cana-de-açúcar. São Paulo: Copersucar, 1988, 19 p. (Série Agronômica, 16).

BIGGS, I. M.; STEWART, G. R.; WILSON, J. R.; CRITCHLEY, C. N- ${ }^{15}$ natural abundance studies in Australian commercial sugarcane. Plant and Soil, 238:21-30, 2002.

BODDEY, R. M. Biological nitrogen fixation in sugarcane: a key to energetically viable bio-fuel production. CRC Critical Review in Plant Science, 14:263-279, 1995.

BODDEY, R. M.; SOARES, L. H. B.; ALVES, B. J. R.; URQUIAGA, S. Bio-ethanol production in Brazil. In: PIMENTEL, D. (Ed.). Renewable energy systems: Environmental and Energetic Issues. Nova York: Springer, 2008.

BODDEY, R. M.; URQUIAGA, S.; ALVES, B. J. R.; REIS, V. M. Endophytic nitrogen fixation in sugarcane: present knowledge and future applications. Plant and Soil, 252:139-149, 2003.

BOLOGNA-CAMPBELL, I. Balanço de nitrogênio e enxofre no sistema solo-planta-cana-de-açúcar no ciclo de cana-planta. 2007. 112 f. Dissertação (Doutorado) - Escola Superior de Agricultura Luiz de Queiroz, Piracicaba, 2007.

BOLSANELLO, J.; WEBER, H.; AZEREDO, D. F. Adubação fosfatada da cana-de-açúcar: doses e complementação. V Congresso Nacional da STAB. Águas de São Pedro: Anais... 1993, p. 65-69.

CABALLERO-MELLADO, J.; MARTINEZ-AGUILAR, L.; PAREDES-VALDEZ, G.; ESTRADA-de los SANTOS, P. Bulkholderia unamae sp., a $\mathrm{N}_{2}$-fixing rhizospheric and endophytic species. International Journal of Systematic Evolutionary Microbiology, 54:1165-1172, 2004.

CAMBRIA, S.; BONI, P. S.; STRABELLI, J. Estudos preliminares com micronutrientes - zinco. Piracicaba: Boletim Técnico Copersucar, 46:12-17, 1989.

CANTARELLA, H. Nitrogênio. p. 375-470. In: NOVAIS, R. F.; ALVAREZ, V., V. H.; BARROS, N. F.; FONTES, R. L. F.; CANTARUTTI, R. B; NEVES, J. C. L. (Ed.). Fertilidade do solo. Viçosa: Sociedade Brasileira de Ciência do Solo, 2007. 1.017 p.

CANTARELLA, H.; TRIVELIN, P. C. O.; VITTI, A. C. Nitrogênio e enxofre na cultura da cana de açúcar. p. 355412. In: YAMADA, T.; ABDALLA, S. R. S.; VITTI, G. C. (Ed.). Nitrogênio e enxofre na agricultura brasileira. Piracicaba: International Plant Nutrition Institute IPNI, 2007, 722 p.
CANTARELLA, H.; ROSSETTO, R.; BARBOSA, W.; PENNA, M. J; RESENDE, L. C. L. Perdas de N por volatilização da amônia e resposta da cana-de-açúcar à adubação nitrogenada em sistema de colheita de cana sem queima prévia. In: VII Congresso Nacional da STAB. Londrina: Anais..., 7:82-87, 1999.

CANTARELLA, H.; ROSSETTO, R.; LANDELL, M. G. A.; BIDÓIA, M. A. P.; VASCONCELOS, A. C. M. Misturas em diferentes proporções de fosfato natural reativo e fosfato solúvel em água para a cana-de-açúcar. In: VIII Congresso Nacional da STAB. Recife: Anais..., p. 218-224, 2002.

CANTARELLA, H.; TRIVELIN, P. C. O.; CONTIN, T. L. M.; DIAS, F. L. F.; ROSSETTO, R.; MARCELINO, R.; COIMBRA, R. B.; QUAGGIO, J. A. Ammonia volatilisation from urease inhibitor-treated urea applied to sugarcane trash blankets. Scientia Agricola, 65:397-401, 2008.

CHALITA, R. Calibração da adubação potássica através da análise química do solo para a cultura da cana-deaçúcar. 1991. 75 f. Dissertação (Mestrado) - Escola Superior de Agricultura Luiz de Queirós, Piracicaba, 1991.

CHAPMAN, L. S.; HAYSOM, M. B. C.; SAFFIGNA, P. G. N cycling in cane fields from ${ }^{15} \mathrm{~N}$ labelled trash and residual fertilizer. Proceedings of the Australian Society of Sugarcane Technologists, Conferência 1992, p. 84-89, 1992. COLETI, J. T.; CASAGRANDE, J. C.; STUPIELLO, J. J.; RIBEIRO, L. O. OLIVEIRA, G. R. Remoção de macronutrientes pela cana-planta e cana-soca, em agrissolos, variedades RB 835486 e SP 81-3250. In: VIII Congresso Nacional da STAB. Recife. Anais..., 2002, p. 316-321.

COLETI, J. T.; LORENZETTI, J. M.; FREITAS, P. G.; CARBINI, J. L. Uso de subprodutos de compostagem em comparação com torta-de-filtro na adubação da cana-planta e seus efeitos na soca, em solos de alta e baixa fertilidade natural. Stab - Açúcar, Álcool e Subprodutos, 4:33-39, 1986.

COSTA, M. C. G.; VITTI, G. C.; CANTARELLA, H. Volatilização de $\mathrm{N}_{-} \mathrm{NH}_{3}$ de fontes nitrogenadas em cana-deaçúcar colhida sem despalha a fogo. Revista Brasileira de Ciência do Solo, 27:631-637, 2003.

CRUTZEN, P. J.; MOSIER, A. R.; SMITH, K. A.; WINIWARTER, W. N2O release from agro-biofuel production negates global warming reduction by replacing fossil fuels. Atmospheric Chemistry and Physics, 8, 389-395, 2008. DEMATTÊ, J. L. I. Cultura da cana-de-açúcar - Recuperação e manutenção da fertilidade dos solos. Piracicaba: Informações Agronômicas N. 111, Setembro 2005. 24 p. DENMEAD. O. T.; FRENEY, J. R.; JACKSON, A. V.; SMITH, J. W. B.; SAFFIGNA, P. G.; WOOD, A. W.; CHAPMAN, L. $\mathrm{S}$. Volatilisation of ammonia from urea and ammonium sulfate applied to sugarcane trash in North Queensland. 
Proceedings of the Australian Society of Sugarcane Technologists, Conferência 1990. p 73-78. 1990.

DOBEREINER, J. Nitrogen-fixing bacteria of the genus Beijerinchia Derx in the rhizosphere of sugarcane. Plant and Soil, 15:211-217, 1961.

DOBERMANN, A. Nitrogen use efficiency - state of the art. In: International Workshop on Enhanced-Efficiency Fertilizers. Frankfurt, 2005. Proceedings. Paris, International Fertilizer Industry Association. 2005. 16 p. CD-ROM.

DONZELLI, J. L. Uso de fertilizantes na cana-de-açúcar no Brasil. In: MACEDO, I. C. (Org.) A energia da cana-deaçúcar. 2 ed. São Paulo: Única, 2007. 246 p.

ESPIRONELO, A. Estudos sobre efeitos do boro na canade-açúcar (Saccharum spp) cultivada em alguns solos do município de Piracicaba. 1972. 58 f. Tese (Doutorado) - Escola Superior de Agricultura Luiz de Queiróz, Piracicaba, 1972.

ESPIRONELO, A.; CANTARELLA, H.; IGUE, T.; NELLI, E. J.; COLETI, J. T.; BOVI, V.; RAMOS, M. T. B. Aplicação de aquamônia, ureia, nitrato de amônio e cloreto de potássio em cinco níveis, em três socas de cana-deaçúcar. In: IV Congresso Nacional da STAB. Olinda, Anais..., 4:94-102, 1987.

FARQUHAR, G. D.; FIRTH, P. M.; WETSELLAR, R.; WEIR, $B$. On the gaseous exchange of ammonia between leaves and the environment: determination of the ammonia compensation point. Plant Physiology, 66:710-714, 1980.

FIELD, C. B.; CAMPBELL, J. E.; LOBELL, D. B. Biomass energy: the scale of the potential resource. Trends in Ecology and Evolution, 23: 65-72, 2007.

FRANCO, H. C. J.; CANTARELLA, H.; TRIVELIN, P. C. O.; VITTI, A. C.; OTTO, R.; FARONI, C. E.; SARTORI, R. H.; TRIVELIN, M. O. Acúmulo de nutrientes pela canaplanta. Stab Açúcar, Álcool e Subprodutos, 26(5):4145, 2008a.

FRANCO, H. C. J.; SARTORI, R. H.; OTTO, R.; FARONI, C. E.; VITTI, A. C.; TRIVELIN, P. C. O. Produtividade e atributos tecnológicos da cana-de-açúcar, relacionados à aplicação de zinco na cana-planta. In: IX Congresso Nacional da STAB, Maceió, Anais..., 9:349-354, 2008b.

FRANCO, H. C. J.; TRIVELIN, P. C. O.; OTTO, R.; FARONI, C. E.; VITTI, A. C.; SARTORI, R. H.; CANTARELLA, H. Acúmulo de nitrogênio, fósforo e potássio, durante o ciclo de cana-planta, relacionados à adubação nitrogenada de plantio, IX Congresso Nacional da STAB. Maceió, Anais..., 9:228-234, 2008c.

FRENEY, J. R.; DENMEAD, O. T.; WOOD, A. W.; SAFFIGNA, P. G.; CHAPMAN, L. S.; HAM, G. J.; HERNEY, A. P.; STEWART, R. L. Factors controlling ammonia loss from trash covered sugarcane fields fertilized with urea. Fertilizer Research, 31:341-349, 1992.

FUENTES-RAMIREZ, L. E.; CABALLERO-MELLADO, J.; SEPULVEDA, J.; MARTINEZ-ROMERO, E. Colonization of sugarcane by Acetobacter diazotrophicus is inhibited by high $\mathrm{N}$ fertilization. FEMS Microbiology Ecology, 29:117-128, 1999.

GAVA, G. J. C.; TRIVELIN, P. C. O.; OLIVEIRA, M. W.; VITTI, A. C.; PENATTI, C. P. Perdas de amônia proveniente da mistura de vinhaça e uréia aplicada ao solo com e sem cobertura de palha de cana-de-açúcar. Stab - Açúcar Alcool e Subprodutos, Piracicaba, 19:40-42, 2001a.

GAVA, G. J. C.; TRIVELIN, P. C. O.; VITTI, A. C.; OLIVEIRA, M. W. Recuperação do nitrogênio $\left({ }^{15} \mathrm{~N}\right)$ da ureia e da palhada por soqueira de cana-de-açúcar (Saccharum spp.). Revista Brasileira de Ciência do Solo, 27: 621630, 2003.

GAVA, G. J. C; TRIVELIN, P. C. O.; OLIVEIRA, M. W.; PENATTI, C. P. Crescimento e acúmulo de nitrogênio em cana-de-açúcar cultivada em solo coberto com palhada. Pesquisa Agropecuária Brasileira, Brasília, 36:1347$1354,2001 b$.

GRAHAM, M. H.; HAYNES, R. J.; MEYER, J. H. Changes in soil fertility induced by trash retention and fertiliser applications on the long-term trash management trial at Mount Edgecombe. Proceedings of the South Africa Sugar Technologist Association, v. 74, p. 109-113, 2000.

GRAHAM, M. H.; HAYNES, R. J.; MEYER, J. H. Green cane harvesting promotes accumulation of soil organic matter and an improvement in soil health. Proceedings of the South Africa Sugar Technologist Association, 73:53-57, 1999.

GRAHAM, M. H.; HAYNES, R. J.; MEYER, J. H. Soil organic matter content and quality: effects of fertilizer applications, burning and trash retention on a long-term sugarcane experiment in South Africa. Soil Biology and Biochemistry, 34:93-102, 2002.

HARTEMINK, A. E. Sugarcane for bioethanol: soil and environmental issues. Advances in Agronomy, 99:125$182,2008$.

HAYSOM, M. B.; CHAPMAN, L. S.; VALLIS, I. Recovery of nitrogen from ${ }^{15} \mathrm{~N}$ urea applied to a green cane trash blanket at Mackay. Proceedings of the Australian Society of Sugarcane Technologists, Conferência 1990. p. 79-84, 1990 .

HOEFSLOOT, G.; TERMORSHUIZEN, A. J. L; WATT, D. A.;CRAMER, M. D. Biological nitrogen fixation is not a major contributor to the nitrogen demand of a commercially grown South African sugarcane cultivar. Plant and Soil, 277:85-96, 2005. 
HOWARTH, R. W.; MARINO, R. Nitrogen as the limiting nutrient for eutrophication in coastal marine ecosystems: evolving views over three decades. Limnology and Oceonography, 51:364-376, 2006.

INTERGOVERNMENTAL PANEL ON CLIMATE CHANGE - IPCC. 2006. IPCC guidelines for national greenhouse gas inventories programme. Volue 4: Agriculture, forestry and other land use. EGGLESTON, H. S.; BUENDIA, L.; MIWA, K.; NGARA, T.; TANABE, K. (Ed.) Hayama, Institute for Global Environmental Strategies, 2006.

JAMES, E. K.; OLIVARES, F. L. Infection and colonization of sugarcane and other graminaceous plants by endophytic diazotrophs. Critical Reviews in Plant Sciences, 17:77-119, 1997.

KENNEDY, I. R.; CHOUDHURY, A. T. M. A.; KECSKÉS, M. L. Non-symbiotic bacterial diazotrophs in crop-farming systems: can their potential for plant growth promotion be better exploited? Soil Biology \& Biochemistry, 36:1229-1244, 2004.

KORNDÖRFER, G. H. Fósforo na cultura da cana-deaçúcar. p. 291-305. In: YAMADA, T.; ABDALLA, S. R. S. (Ed.) Fósforo na agricultura brasileira. Piracicaba: Potafós, 2004. 726 p.

KORNDÖRFER, G. H. Silício. p. 337-346. In: DINARDOMIRANDA, L. L.; VASCONCELOS, A. C. M.; LANDELL, M. G. A. (Ed.) Cana-de-açúcar. Campinas, Instituto Agronômico, 2008. 882 p.

KORNDÖRFER, G. H.; OLIVEIRA, L. A. O potássio na cultura da cana-de-açúcar. p. 469-490. In: YAMADA, T.; ROBERTS, T. L. (Ed.) Potássio na agricultura brasileira. Piracicaba: Potafós, 2005. 841 p.

KORNDÖRFER, G. H.; RIBEIRO, A. C.; ANDRADE, L. A. B. Cana-de-açúcar. In: RIBEIRO, A. C.; GUIMARÃES, P. T. G.; ALVARES, V. V. H. Recomendações para o uso de corretivos e fertilizantes em Minas Gerais. $5^{\mathrm{a}}$. Aproximação. Viçosa: Comissão de Fertilidade de Minas Gerais, 1999. 359 p.

LAGREID, M.; BOCKMAN, O. C.; KAARTAD, O. Agriculture fertilizers and the environment. Wallingford: CABI Publishing, 1999, 294 p.

LEGENDRE, B. L. Sugarcane Production Handbook 2001. Baton Rouge: Louisiana State University Agricultura Center, Louisiana Cooperative Extension. 2001. 54 p.

LUCA, E. F. Matéria orgânica e atributos do solo em sistemas de colheita com e sem queima da cana-deaçúcar. 2002. 101 f. Tese (Doutorado) - Universidade de São Paulo, Centro de Energia Nuclear na Agricultura, Piracicaba, 2002.

MACEDO, I. C.; SEABRA, J. E.; SILVA, J. E. A. R. Greenhouse gases emissions in the production and use of ethanol from sugarcane in Brazil: the 2005/2006 aver- ages and a prediction for 2020. Biomass and Bionergy, 32:582-595, 2008.

MARINHO, M. L.; AlBUQUERQUE, G. A. C. Calagem. In: ORLANDO FILHO, J. (Ed.) Nutrição e adubação da cana-de-açúcar no Brasil. Piracicaba: Planalsucar, 1983. p. 179-208.

MARINHO, M. L.; ALBUQUERQUE, G. A. C. Efeito do cobre e do zinco na produção de cana-de-açúcar em solos de tabuleiros de Alagoas. Brasil Açucareiro, 98:41-50, 1981.

MARQUES JR, R. B.; CANELLAS, L. P.; SILVA, L. G.; OLIVARES, F. L. Promoção de enraizamento de microtoletes de cana-de-açúcar pelo uso conjunto de substâncias húmicas e bactérias diazotróficas endofíticas. Revista Brasileira de Ciência do Solo, 32: 1121-1128, 2008.

MEIER, E. A; THORBURN, P. J.; WEGENER, M. K.; BASFORD, K. E. A conceptual analysis of nitrogen trash blankets in the wet tropics. Sugarcane International, maio-jun., p. 8-11, 2002.

MELliS, E. V.; QUAGGIO, J. A.; CANTARELLA, H. Micronutrientes. p. 331-335. In: DINARDO-MIRANDA, L. L.; VASCONCELOS, A. C. M.; LANDELL, M. G. A. (Ed.) Cana-de-açúcar. Campinas, Instituto Agronômico, 2008. 882 p.

MORELLI, J. L. DEMATTÊ, J. L. I., NELLI, E. J.; DALBEN, A. E. Efeito do gesso e do calcário nas propriedades químicas de solos arenosos álicos e na produção da cana-de-açúcar. Stab Açúcar, álcool e subprodutos, 6:24-31, 1987.

MORELli, J. L.; DALBEN, A. E.; ALMEIDA, J. O. C.; DEMATTÊ, J. L. I. Calcário e gesso na produtividade da cana-de-açúcar e nas características químicas de um Latossolo de textura média álico. R. Bras. Ci. Solo, 16:187-194, 1992.

MOURA FILHO, G.; SILVA, L. C.; ALMEIDA, A. C. S.; SOUZA, J. L.; TEODORO, I.; BARBOSA, G. V. S.; SILVA, V. T.; MOURA, A. B. Extração e exportação de nutrientes pelas cultivas RB92579 e RB93509 no ciclo de canaplanta. In: IX Congresso Nacional da STAB. Maceió, Anais..., 9:307-311, 2008.

MUÑOZ-ROJAS, J.; CABALLERO-MELLADO, J. Population dynamics of Glucanacetobacter diazotrophicus in sugarcane cultivars and its effect on plant growth. Microbial. Ecol., 46:454-464, 2003.

NG KEE KWONG, K. F.; DEVILLE, J. The course of fertilizer nitrogen uptake by rainfed sugarcane in Mauritius. Journal of Agricultural Science, 122:385-391, 1994.

NG KEE KWONG, K. F.; DEVILLE, J.; CAVALOT, P. C.; RIVIERE, V. Value of cane trash in nitrogen nutrition of sugarcane. Plant and Soil, 102:79-83, 1987. 
OLIVEIRA, A. L. M.; CANUTO, E. L.; REIS, V. M.; BALDANI, J. I. Response of micropropagated sugarcane varieties to inoculation with endophytic diazotrophic bacteria. Brazilian Journal of Microbiology 34 (Suppl.1):59-61, 2003.

OLIVEIRA, A. L. M.; CANUTO, E. L.; URQUIAGA, S.; REIS, V. M.; BALDANI, J. I. Yield of micropropagated sugarcane varieties in different soil types following inoculation with diazotrophic bacteria. Plant and Soil, 284:230-32, 2006.

OLIVEIRA, A. L. M.; URQUIAGA, S.; DOBEREINER, J.; BALDANI, J. I. The effect of inoculating endophytic N2fixing bacteria on micropropagated sugarcane plants. Plant and Soil, 242:205-215, 2002.

OLIVEIRA, O. C. de; URQUIAGA, S.; BODDEY, R. M. Burning cane: the long-term effects. International Sugar Journal, 94 (n.1147E):272-275, 1994.

ORLANDO FILHO, J.; BITTENCOURT, V. C.; ALVES, M. C. Aplicação de vinhaça em solo arenoso do Brasil e poluição do lençol freático com nitrogênio. In: VI Congresso Nacional da STAB. Rio de Janeiro, Anais..., 6:14-17, 1995.

ORLANDO FILHO, J.; ROSSETTO, R.; CASAGRANDE, A. A. Cana-de-açúcar. p. 355-373. In: FERREIRA, M. E.; CRUZ, M. C. P.; RAIJ, B van; ABREU, C. A. (Ed.) Micronutrientes e elementos tóxicos na agricultura. Jaboticabal: CNPQ/Fapesp/Potafós, 2001. 600 p.

ORLANDO FILHO, J.; ZAMBELLO JR., E.; RODELLA, A. A. Calibração de potássio no solo e recomendação de adubação para a cana-de-açúcar. Brasil Açucareiro, 97(1):18-24, 1980

PENATTI, C. P.; DONZELLI, J. L.; FORTI, J. A. Doses de nitrogênio em cana-planta. In: VII Seminário de Tecnologia Agronômica. Piracicaba, 1997. Anais..., Piracicaba: Centro de Tecnologia da Copersucar, 1997. p. 340-349.

PENATTI, C. P.; FORTI, J. A. Calcário e gesso em canade-açúcar. Relatório de projeto. Piracicaba: Copersucar, 1993. $80 \mathrm{p}$.

PERIN, L.; MARTINEZ-AGUILAR, L.; PAREDES-VALDEZ, G.; BALDANI, J. I.; ESTRADA DE LOS SANTOS; P.; REIS, V. M.; CABALLERO-MELADO, J. Burkholderia silvatlantica sp nov., a novel diazotrophic bacterium associated with sugarcane and maize. International Journal of Systematic and Evolutionary Microbiology, 56: 1931-1937, 2006.

PIÑON, D.; CASAS, M.; BLANCH; M.; FONTANIELLA, B; BLANCO, Y.; VICENT, C; SOLAS, M. T.; LEGAZ, M. E. Gluconacetobacter diazotrophicus, a sugarcane emdosymbiont, produces a bacteriocin against Xantomonas albilineans, a sugarcane pathogen. Research in Microbiology, 153:345-351, 2002.
POLIDORO, J. C.; RESENDEA. S.; QUESADA, D. M.; XAVIER, R. P.; COELHO, C. H. M.; AlVES, B. J. R.; BODDEY, R. M.; URQUIAGA, S. Levantamento da contribuição da fixação biológica de nitrogênio para a cultura da cana-de-açúcar no Brasil. Seropédica: Embrapa Agrobiologia, dez. 2001. 8 p. (Embrapa Agrobiologia. Documentos, 144).

PRAMMANEE, P.; SAFFignA, P. G.; WOOD, A. W.; FRENEY, J. R. Loss of nitrogen from urea and ammoinum sulphate applied to sugarcane crop residues. Proceedings of Australian Society of Sugarcane Technologists, Conferência 1989. p. 76-84. 1989.

PRASERTSAK, P.; FRENEY, J. R.; DENMEAD, O. T.; SAFFIGNA, P. G.; GOVE, G. G.; REGHENZANI, J. R. Effect of fertilizer placement on nitrogen loss from sugarcane in tropical Queensland. Nutrient Cycling in Agroecosystems, 62:229-239, 2002.

QUAGGIO, J. A.; RAIJ, B. van. Cálcio, magnésio e correção da acidez do solo. p. 313-321. In: DINARDO-MIRANDA, L. L.; VASCONCELOS, A. C. M.; LANDELL, M. G. A. (Ed.) Cana-de-açúcar. Campinas: Instituto Agronômico, 2008. 882 p.

RAIJ, B. van; CANTARELlA, H.; QUAGGIO, J. A.; FURLANI, A. M. C. Recomendações de adubação e calagem para o Estado de São Paulo. Campinas: Instituto Agronômico. 1997. 285 p. (Boletim Técnico, 100).

RAIJ, B. van. Calibração do potássio trocável em solos para feijão, algodão e cana-de-açúcar. Ciência e Cultura, 26:575-576, 1974.

RAIJ, B. van. Gesso na agricultura. Campinas: Instituto Agronômico. 2008. 233 p.

REIS, V. M.; BALDANI, J. I.; BALDANI, V. L.; DÖBEREIN$\mathrm{ER}, \mathrm{J}$. Biological di-nitrogen fixation in gramineae and palm trees. Critical Reviews in Plant Science, 19:227247, 2000.

REIS, V. M.; ESTRADA DE LOS SANTOS; P.; TENORIOSALGADO, S.; VOLGEL, J.; STROFFELS, M.; GUYON, S.; MAVINGUI, P.; BALDANI, V. L.; SCHMID, M.; BALDANI, J. I; BALANDREAU, J.; HARTMANN, A.; CABALLERO-MELADO, J. Burkholderia tropica sp. nov., a novel nitrogen-fixing, plant-associated bacterium. International Journal of Systematic and Evolutionary Microbiology, 54:2155-2162, 2004.

REIS, V. M.; URQUIAGA, S.; PEREIRA, W.; HIPÓLITO, G.; BARROS, J. C.; FIUSA, R.; LEITE, J. M. Resposta de duas variedades de cana-de-açúcar à inoculação com bactérias diazotróficas. In: IX Congresso Nacional da STAB, Maceió, 9:681-686, 2008.

RICE, R. W.; GILBER, R.; LENTINI, R. S. Nutritional requirements for Florida sugarcane. Gainesville: University 
of Florida. Institute of Food and Agricultural Sciences Extension. 2006. 8 p. (SS-AGR, 228).

ROSSETTO, R.; SPIRONELLO, A.; CANTARELlA, H.; QUAGGIO, J. A. Calagem para a cana-de-açúcar e sua interação com a adubação potássica. Bragantia, 63: 105-119, 2004.

ROSSETTO, R.; DIAS, F. L. F.; VITTI, A. C. Fertilidade do solo, nutrição e adubação. p. 221-237. In: DINARDOMIRANDA, L. L.; VASCONCELOS, A. C. M.; LANDELL, M. G. A. (Ed.) Cana-de-açúcar. Campinas: Instituto Agronômico, 2008a. 882 p.

ROSSETTO, R.; DIAS, F. L. F.; VITTI, A. C.; PRADO Jr., J. P. Q. Fósforo. p. 271-287. In: DINARDO-MIRANDA, L. L.; VASCONCELOS, A. C. M.; LANDELL, M. G. A. (Ed.) Cana-de-açúcar. Campinas: Instituto Agronômico, 2008b. 882 p.

ROSSETTO, R.; DIAS, F. L. F.; VITTI, A. C.; TAVARES, S. Potássio. p. 289-312. In: DINARDO-MIRANDA, L. L.; VASCONCELOS, A. C. M.; LANDELL, M. G. A. (Ed.) Cana-de-açúcar. Campinas: Instituto Agronômico, 2008c. 882 p.

ROSSETTO, R.; FARHAT, M.; FURLAN, R.; GIL, M. A.; SILVA, S. F. Eficiência agronômica do fosfato natural na cultura da cana-de-açúcar. In: VIII Congresso Nacional da STAB. Recife, Anais..., 6:276-282, 2002

ROSSETTO, R.; KORNDÖRFER, G. H.; DIAS, F. L. Nutrição e adubação da cana-de-açúcar. In: MARQUES, M. O.; MUTTON, M. A.; NOGUEIRA, T. A. R.; TASSO JR., L. C.; NOGUEIRA, G. A.; BERNARDI, J. H. (Ed.). Tecnologias na Agroindústria Canavieira. Jaboticabal: Unesp, p. 125-139. 2008d.

SAMPAIO, E. V. S. B.; SALCEDO, I. H.; BETTAMY, J. Dinâmica de nutrientes em cana-de-açúcar. I. Eficiência de utilização de ureia- ${ }^{15} \mathrm{~N}$ em aplicação única ou parcelada. Pesquisa Agropecuária Brasileira, 19:943-949, 1984.

SANTOS, M. A. C.; SOBRAL, F. A calibration of copper in sugarcane in Northeast Brazil. In: XVII Congress of the International Society of Sugarcane Technologists, Manilla. 1980. Proceedings. Manilla, International Society of Sugarcane Technologists, 1980. p. 411-420.

SCAVIA, D.; BRICKER, S. Coastal eutrophication assessment in the United States, Biogeochemistry, 79:187208, 2006.

SCHARLEMANN, J.P.W.; LAURANCE, W.F. How green are biofuels? Science, 349: 43-44, 2008.

SCHJOERRING, J. K.; HUSTED, S.; MATTSSON, M. Physiological parameters controlling plant-atmospheric ammonia exchange. Atmospheric Environment, 32:491498, 1998.

SEVILLA, M.; BURRIS, R. H.; GUNAPALA, N.; KENNEDY, C. Comparison of benefit to sugarcane plant growth and
${ }^{15} \mathrm{~N}_{2}$ incorporation following inoculation of sterile plants with Acetobacter diazotrophicus wild-type and Nifmutant strains. Molecular Plant-Microbe Interactions, 14:358-366., 2001.

SILVA, G. M. A.; CASTRO, L. J. P.; MAGRO, J. A. Comportamento agroindustrial da cana-de-açúcar em solo irrigado e não irrigado com vinhaça. In: IV Seminário Copersucar da Indústria Açucareira, Águas de Lindóia, Anais..., 1976. p. 107-122.

SOBRAL, F. A.; WEBER, H. Nutrição mineral da canade-açúcar (micronutrientes). In: ORLANDO FILHO, J. (Coord.) Nutrição e adubação da cana-de-açúcar no Brasil. Piracicaba: IAA-Planalsucar, 1983. p. 103-122.

SOUSA, D. M. G.; LOBATO, E. (Ed.). Cerrado: correção do solo e adubação. Planaltina: Embrapa cerrados, 2002, 416 p.

SPIRONELlO, A. RAIJ, B. van; PENATTI, C. P.; CANTARELLA, H.; MORELLI, J. L.; ORLANDO FILHO, J.; LANDELL, M. G. A.; ROSSETTO, R. Cana-de-açúcar. In: RAIJ, B. van; CANTARELLA, H.; QUAGGIO, J. A.; FURLANI, A. M. C. (Ed.) Recomendações de adubação e calagem para o Estado de São Paulo. Campinas: Instituto Agronômico. 1997. 285 p. (Boletim Técnico, 100). TASSO Jr., L. C.; MARQUES, M. O.; CAMILOTTI, F.; SILVA, T. Exportação de macronutrientes em cinco variedades de cana-de-açúcar cultivadas na região centro-norte do Estado de São Paulo. Stab Açúcar, Álcool e Subprodutos, 25(6):38-42, 2007

TEJEDA, N.; LLUCH, C.; MATÍNEZ-TOLEDO, M. V.; GOZÁLEZ-LÓPEZ, J. Isolation and charaterization of Azootobacter and azospirillum strains from sugarcane rhizosphere. Plant and Soil, 270:223-232, 2005.

THORBURN, P. J.; KEATING, B. A.; ROBERTSON, F. A.; WOOD, A. W. Long-term changes in soil carbon and nitrogen under trash blanketing. Proceedings of the Australian Society of Sugarcane Technologists, Conferência 2000, p. 217-224, 2000.

THORBURN, P. J.; PROBERT, M. E.; LISSON, S.; WOOD, A. W.; KEATING, B. A. Impacts of trash retention on soil nitrogen and water: an example from the Australian sugarcane industry. Proceedings of the South Africa Sugar Technologist Association, 73:75-79, 1999.

THORBURN, P. J.; van ANTWERPEN, R.; MEYER, J. H.; BEZUIDENHOUT, C. N. The impact of trash management on soil carbon and nitrogen: I Modelling long-term experimental results in the South African sugar industry. Proceedings of the South Africa Sugar Technologist Association, 76:260-268, 2002.

THORBURN, P. J; DART, I. K.; BIGGS, I. M.; BAILLIE, C. P.; SMITH, M. A.; KEATING, B. A. The fate of nitrogen 
applied to sugarcane by trickle irrigation. Irrigation Science, 22:201-209, 2003.

TRIVELIN, P. C. O.; OLIVEIRA, M. W.; VITTI, A. C.; GAVA, G. J. C.; BENDASSOLLI, J. A. Perdas de nitrogênio da uréia no sistema solo-planta em dois ciclos de cana-de-açúcar. Pesquisa Agropecuária Brasileira, 37:193-201, 2002a.

TRIVELIN, P. C. O.; VICTORIA, R. L.; RODRIGUES, J. C. S. Aproveitamento por soqueira de cana-de-açúcar de final de safra do nitrogênio da aquamônia- ${ }^{15} \mathrm{~N}$ e ureia- ${ }^{15} \mathrm{~N}$ aplicado ao solo em complemento à vinhaça. Pesquisa Agropecuária Brasileira, 30:1375-1385, 1995.

TRIVELIN, P. C. O.; VITTI, A. C.; OLIVEIRA, M. W.; GAVA, G. J. C.; SARRIÉS, G. A. Utilização de nitrogênio e produtividade da cana-de-açúcar (cana-planta) em solo arenoso com incorporação de resíduos da cultura. Revista Brasileira de Ciência do Solo, 26:636-646, $2002 b$.

URQUIAGA, S.; CRUZ, K. H. S.; BODDEY, R. M. Contribution of nitrogen fixation to sugarcane: nitrogen-15 and nitrogen-balance estimates. Soil Science Society of America Journal, 56:105-114, 1992.

VITTI, A. C. Adubação nitrogenada da cana-de-açúcar (soqueira) colhida mecanicamente sem a queima prévia: manejo e efeito na produtividade. 2003. 114 f. Tese (Doutorado) - Universidade de São Paulo, Piracicaba, Centro de Energia Nuclear na Agricultura, 2003.

VITTI, A. C.; CANTARElla, H.; TRIVElin, P. C. O.; BOLOGNA-CAMPBELL, I. Enxofre. p. 323-330. In: DINARDO-MIRANDA, L. L.; VASCONCELOS, A. C. M.; LANDELL, M. G. A. (Ed.) Cana-de-açúcar. Campinas: Instituto Agronômico, 2008a. 882 p.

VITTI, A. C.; CANTARElla, H.; TRIVElin, P. C. O.; ROSSETTO, R. Nitrogênio. p. 239-269. In: DINARDOMIRANDA, L. L.; VASCONCELOS, A. C. M.; LANDELL, M. G. A. (Ed.) Cana-de-açúcar. Campinas: Instituto Agronômico, 2008b. 882 p.

VITTI, A. C.; TRIVELIN, P. C. O.; FRANCO, H. C. J.; OTTO, R.; FARONI, C. E.; CANTARELLA, H. Recuperação pela cana-de-açúcar do $\mathrm{N}$ dos resíduos culturais e da adubação nitrogenada de plantio. IX Congresso Nacional da STAB. Maceió, Anais..., 9:360-365, 2008c.

VITTI, A. C.; TRIVELIN, P. C. O.; GAVA, G. J. C.; OLIVEIRA, M. W.; PENATTI, C. P. Efeito residual da adubação nitrogenada $(15 \mathrm{~N})$ no ciclo subsequente da cultura de cana-de-açúcar (CD). Reunião Brasileira de Fertilidade do solo e Nutrição de Plantas, 25, 2002, Rio de Janeiro. Anais... SBCS, 2002a.

VITTI, A. C.; TRIVELIN, P. C. O.; GAVA, G. J. C.; PENATTI, C. P. Produtividade da cana-de-açúcar relacionada à localização de adubos nitrogenados sobre a palha. Stab Açúcar, Alcool e Subprodutos, 23(5):30-35, 2005.

VITTI, G. C.; MALAVOLTA, E.; FERREIRA, M. E. Resposta de culturas anuais e perenes à aplicação de enxofre. In: BORKERT, C. M.; LANTMANN, A. F. (Ed.). Enxofre e micronutrientes na agricultura brasileira. Londrina: Sociedade Brasileira de Ciência do Solo, 1988. p. 61-85. VITTI, G. C.; MAZZA, J. A. Planejamento, estratégias de manejo e nutrição da cultura de cana-de-açúcar. Informações Agronômicas. Piracicaba: Potafós, 2002. 16 p. VITTI, G. C.; MAZZA, J. A.; PEREIRA, H. S.; DEMATTÊ, J. L. I. Resultados experimentais do uso de gesso na agricultura - cana-de-açúcar. In: II Seminário sobre o uso do gesso na agricultura. Uberaba: Instituto Brasileiro do Fosfato, 1992. p. 191-224.

WEBER, H.; DAROS, E.; ZAMBON, J.L.C.; IDO, O.T.; BARELA, J.D. Recuperação de soqueiras de canade-açúcar com adubação N, P e K. Scientia Agraria, 2:315-324, 2002

YONEYAMA, T.; MURAOKA, T.; KIM, T. H.; DACANAY, E. V.; NAKANISHI, Y. The natural ${ }^{15} \mathrm{~N}$ abundance of sugarcane and neighbouring plants in Brazil, the Philippines and Miyako (Japan). Plant and Soil, 189:239-244, 1997. ZAMBELLO JR., E.; ORLANDO FILHO, J. Adubação da cana-de-açúcar na região Centro-Sul do Brasil. Piracicaba: Planalsucar. p. 5-26. 1981 (Boletim Técnico, 3). 
